\title{
Enrichment of Beta cells from the human fetal pancreas by fluorescence activated cell sorting with a new monoclonal antibody
}

\author{
R.R. de Krijger ${ }^{1}$, H.J. Aanstoot ${ }^{1}$, G.Kranenburg ${ }^{1}$, A. Verkerk ${ }^{2}$,J.F.Jongkind ${ }^{2}$, R. van Strik ${ }^{3}$, \\ K.J.Lafferty ${ }^{4}$ and G.J.Bruining \\ Department of ${ }^{1}$ Pediatrics, Erasmus University Rotterdam and University Hospital Sophia Childrens Hospital, Departments of \\ ${ }^{2}$ Cell Biology and ${ }^{3}$ Epidemiology, Biostatistics, Erasmus University Rotterdam, Rotterdam, The Netherlands, and \\ ${ }^{4}$ Barbara Davis Center, University of Colorado, Denver, Colorado, USA
}

\begin{abstract}
Summary. The aim of this study was to produce an antibody reactive to the surface of endocrine pancreatic cells and use this antibody for the purification of endocrine cells from the human fetal pancreas by fluorescence activated cell sorting. We describe such an antibody, called N1, reacting with the surface and cytoplasm of endocrine cells in the adult and fetal human pancreas (12 to 18 weeks gestational age). While unreactive to exocrine and mesenchymal cells, it was not specific for endocrine cells, as evidenced by its staining pattern in tissues other than pancreas. Almost $40 \%$ of the N1-positive pancreatic cells contained either insulin, glucagon or somatostatin. Conversely, more than $90 \%$ of each of the hormonecontaining cells was N1 positive. An additional $40 \%$ of N1positive cells, not containing other pancreatic hormones, was shown to contain islet amyloid polypeptide, synaptophysin,
\end{abstract}

chromogranin, tyrosin hydroxylase or CA812. A two-step collagenase digestion protocol yielded $1.29 \pm 0.17 \times 10^{5}$ cells per mg pancreatic tissue. After Percoll gradient centrifugation, the suspension contained $15.6 \pm 5.7 \% \quad(n=25$, mean $\pm \mathrm{SD}$ ) cells reactive with N1. By fluorescence activated cell sorting using the antibody $\mathrm{N} 1$, the single-cell suspension was enriched from $3.0 \pm 1.4 \%$ to $16.2 \pm 4.8 \% \quad(n=10$, $p<0.01)$ Beta cells. Alpha and Delta cells were also enriched significantly by this procedure. The percentage of N1-positive cells increased from $17 \pm 4 \%$ to $83 \pm 6 \%$. This preparation enriched for endocrine cells allows future studies on possible endocrine precursor cells.

Key words: Monoclonal antibody, human fetal pancreas, endocrine cells, flow cytometry, cell separation, differentiation.
Several antibodies have been reported to react with Beta cells or endocrine pancreatic cells [1-6]. Rat Beta cells or islets were usually the substrate when determining the specificity of these antibodies. Islets of Langerhans constitute $1-2 \%$ of the adult human pancreas. Their recovery is based on enzymatic digestion of the pancreatic glands [7]. Recovery of single endocrine pancreatic cells has been described by physicochemical separation procedures [8]. In the human fetal pancreas, a large proportion of the endocrine cells are located outside the islets, complicating islet isolation procedures [9].

The aim of the present study was to produce antibodies, which after reacting to the surface of human fetal endocrine pancreatic cells, could be used for selective enrichment of these cells by fluorescence activated cell sorting. Such enriched cell preparations could be an important tool in the study of differentiation and proliferation of endocrine pancreatic cells. We describe the production and staining pattern of an antibody, N1, reactive to the surface of Beta cells. Subsequently, a method for the production of single-cell suspensions from the buman fetal pancreas is described. These were labelled with N1 and subjected to fluorescence activated cell sorting. We show a substantial enrichment of Beta cells, Alpha cells and Delta cells.

\section{Materials and methods}

\section{Tissue pre-treatment for immunization}

Human fetal and adult pancreata were obtained with permission of the local ethical committee. Abortions were performed mechanically, resulting in a warm ischaemia time of $10-20 \mathrm{~min}$. The specimens were between 12 and 18 weeks gestational age. For immunization, fetal pancreata were cut into $1 \mathrm{~mm}^{3}$ pieces and cultured for 14 days in serum-free medium HB104 (Hana Biologics, Berkeley, Calif., USA) supplemented with $20 \mathrm{mmol} / 1 \mathrm{HEPES}, 100 \mathrm{IU} / \mathrm{ml}$ penicillin, $100 \mathrm{U} / \mathrm{ml}$ neomycin, $100 \mathrm{mg} / \mathrm{ml}$ streptomycin, $1 \mathrm{mmol} / 1 \mathrm{so}-$ dium pyruvate and $20 \mathrm{mmol} / \mathrm{L} \mathrm{L}$-glutamine. The tissue was cultured under $95 \% \mathrm{O}^{2}$ and $5 \% \mathrm{CO}^{2}$ at $37^{\circ} \mathrm{C}$. Following culture, the tissue fragments were homogenized, centrifuged at $12,000 \mathrm{x} g$ for $5 \mathrm{~min}$ to remove nuclei and other particles, and stored at $-20^{\circ} \mathrm{C}$ until use. 

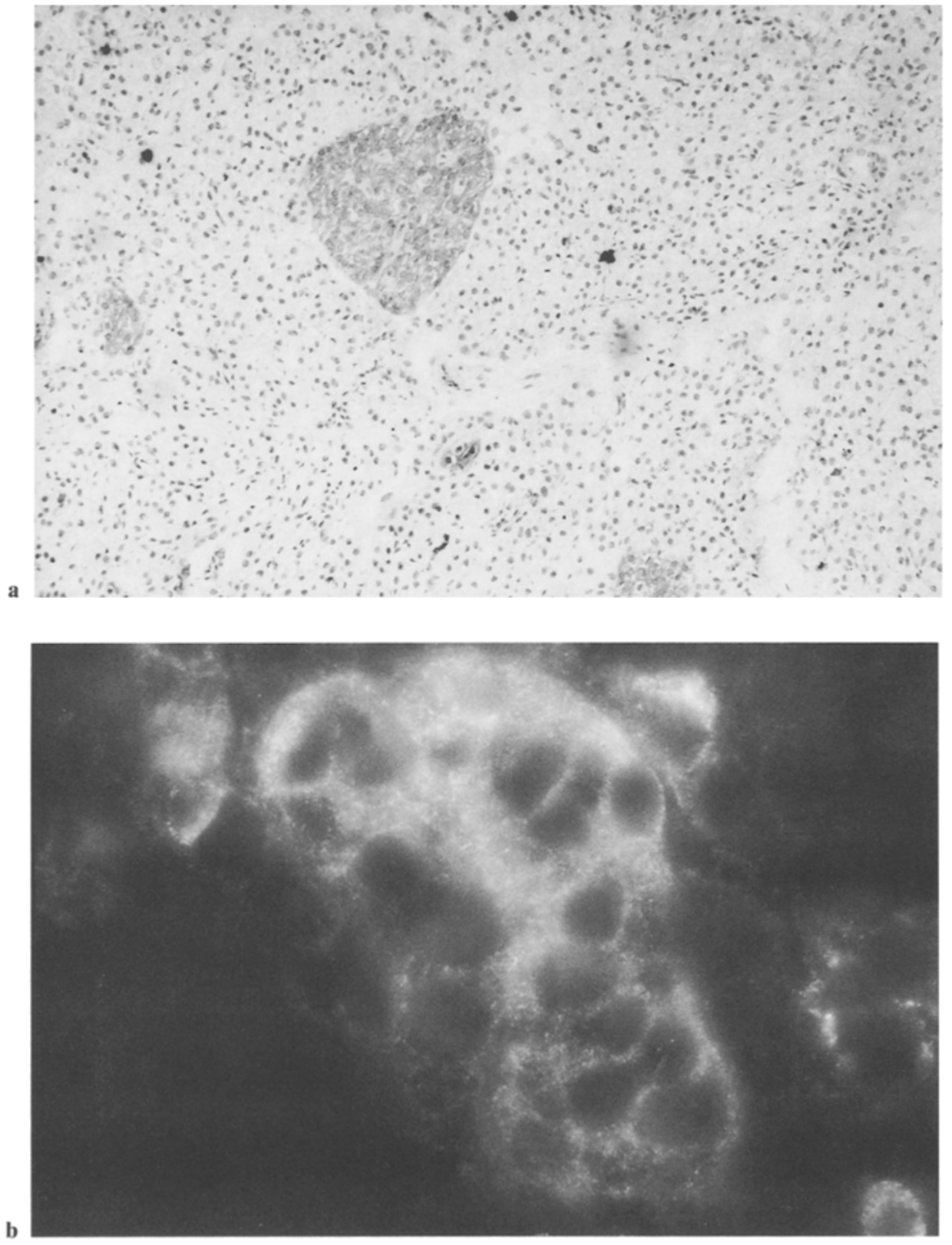

Fig. 1a,b. Sections of human adult (a) or human fetal (b) pancreas stained with N1. In (a) the second antibody is peroxidaselinked and developed with diamino-benzidine, in (b) a fluorescein isothiocyanateconjugated second antibody was used. In both sections N1 stains a cluster of cells representing the islet of Langerhans

\section{Immunization}

C57BI/6J and SJL/J mice were purchased from Jackson Laboratories (Bar Harbor, Me., USA). NZB/N mice were obtained from National Institutes of Health (NIH, Bethesda, Md., USA). The mice were injected intraperitoneally three times with $500 \mu \mathrm{g}$ (wet weight) of homogenized tissue in complete Freund's adjuvant, incomplete Freund's adjuvant and phosphate buffered saline $(137 \mathrm{mmol} / \mathrm{NaCl}$, $8 \mathrm{mmol} / 1 \mathrm{Na}_{2} \mathrm{HPO}_{4} \cdot 2 \mathrm{H}_{2} \mathrm{O}, 2 \mathrm{mmol} / 1 \mathrm{KH}_{2} \mathrm{PO}_{4}, 3 \mathrm{mmol} / \mathrm{KCl}$; PBS), $\mathrm{pH} 7.4$, respectively. The mice received an intravenous boost of $50 \mu \mathrm{g}$ homogenized tissue 3 days before spleen cell harvesting.

\section{Production and screening of antibodies}

Spleen cells of immunized animals were fused with P3X63AG8.653 myeloma cells according to Galfre and Milstein [10] and cultured in hypoxanthine-aminopterin-thymidine (HAT) medium with syngeneic peritoneal macrophages as feeders. After culture at $37^{\circ} \mathrm{C}$ in $5 \% \mathrm{CO}^{2}$ for 14 days, hybridomas were screened by staining cryostat sections of adult human pancreata with the indirect fluorescence technique mentioned below, using culture supernatants as the first antibody step. Positive clones were expanded, subcloned by limiting dilutions and re-tested on human fetal pancreatic sections.

\section{Dispersion}

Human fetal pancreata were minced with scissors to fragments of $1 \mathrm{~mm}^{3}$. The pieces were centrifuged at $100 \mathrm{x} g$ for $1 \mathrm{~min}$. A maximum of $0.4 \mathrm{ml}$ tissue was resuspended per $4 \mathrm{ml}$ Earle's balanced salt solution without $\mathrm{Ca} / \mathrm{Mg}$ (EBSS; Gibco, Paisley, UK) containing collagenase type I (Sigma Chemical Co., St. Louis, Mo, USA, $1 \mathrm{mg} / \mathrm{ml}$ ), and DNase (10 $\mu \mathrm{g} / \mathrm{ml}$, Sigma) and placed in a shaker bath (GFL, Burgwedel, FRG) at $37^{\circ} \mathrm{C}$, for $10 \mathrm{~min}$. The suspension was pipetted up and down for 1-2 min with a glass pipette and centrifuged at $100 \mathrm{x} g$ for $1 \mathrm{~min}$. The pellet was re-incubated with a fresh collagenase solution for another $10 \mathrm{~min}$ and centrifuged again. All glass- 
Table 1. Staining pattern of the monoclonal antibody N1 on several human fetal tissues

\begin{tabular}{llc}
\hline Tissue & Cell type & Reaction \\
\hline Pancreas & Islet cells & ++ \\
Kidney & $\begin{array}{l}\text { Epithelial cells lining } \\
\text { proximal tubules }\end{array}$ & ++ \\
Parathyroid & Chief cells & ++ \\
Duodenum & All cells lining the lumen & ++ \\
Stomach & All cells lining the lumen & + \\
Lung & All cells lining the lumen of bronchi & + \\
Liver & Hepatocytes & + \\
Brain & Neuronal cells & + \\
\hline
\end{tabular}

A strongly positive reaction is indicated by ++ , a positive reaction by +

ware was siliconized. The $100 \mathrm{x} g$ supernatants, containing single cells, were washed, passed through a $100 \mu \mathrm{m}$ nylon mesh (van Wijk, Santpoort, The Netherlands), resuspended and counted in a BurkerTurk counting chamber. Cell numbers were expressed as $10^{6} / \mathrm{mg}$ tissue.

\section{Overnight culture}

After dispersion cells were suspended in RPMI 1640 at a concentration of $1-2 \times 10^{6}$ cells $/ \mathrm{ml}$. The medium was supplemented with $2 \mathrm{mmol} / \mathrm{l}$ L-glutamine (Gibco), $100 \mathrm{NU} / \mathrm{ml}$ penicillin, $100 \mu \mathrm{g} / \mathrm{ml}$ streptomycin and $25 \mu \mathrm{g} / \mathrm{ml}$ Fungizone (Gibco), $25 \mathrm{mmol} / \mathrm{l}$ HEPES (Merck, Darmstadt, FRG), 10\% pooled, heat-inactivated human serum (Bloodbank, University Hospital, Leiden, The Netherlands), $1.5 \mathrm{U} / \mathrm{ml}$ dispase $\mathrm{I}$ (Boehringer Mannheim, Mannheim, FRG) and $10 \mu \mathrm{g} / \mathrm{ml}$ DNase (Sigma). The enzymes were added to prevent cell aggregation or cells attaching to the bottom of the dish. The cells were cultured in a $\mathrm{CO}_{2}$ incubator (Heraeus, Osterode, $\mathrm{FRG}$ ) at $37^{\circ} \mathrm{C}$ and $5 \% \mathrm{CO}_{2}$ for $12-15 \mathrm{~h}$.

\section{Gradient centrifugation}

An iso-osmotic Percoll solution (SIP) was prepared by mixing 90 parts of Percoll (Pharmacia, Uppsala, Sweden) with ten parts 10 times concentrated Hanks' balanced salt solution (HBSS; Gibco) and $10 \mathrm{mmol} / \mathrm{HEPES}$. Working solutions for Percoll gradients were prepared by mixing fixed ratios of SIP and EBSS. A gradient with layers of 1.004 (EBSS), 1.030 and $1.063 \mathrm{~g} / \mathrm{ml}$ was constructed. Following the $12-15 \mathrm{~h}$ culture period, the cells were suspended in the $1.063 \mathrm{~g} / \mathrm{ml}$ Percoll solution and subjected to floatation centrifugation for $25 \mathrm{~min}$ at $400 \mathrm{xg}$ at $20^{\circ} \mathrm{C}$ in a Heraeus Varifuge RF (Heraeus, Ostenrode, FRG) without braking. Subsequently, cells were collected from the interphases and washed three times in EBSS, supplemented with $2.5 \%$ pooled human serum. Finally, the cells were counted, viability and the percentage of insulin-positive cells were assessed.

\section{Immunohistochemistry}

Pancreata from mouse, rat, monkey and humans (adult and fetal) and control organs were snap-frozen through isopentane in liquid nitrogen and stored until use. Cryostat sections were prepared at $5 \mu \mathrm{m}$ thickness and stained after fixation with $4 \%$ buffered formalin or without fixation by an indirect labelling technique, using either fluorescence- or peroxidase-conjugated second antibodies $[11,12]$. N1 was used at a dilution of 1:2000 (ascites) or 1:10 (culture supernatant). Furthermore, an anti-insulin mouse monoclonal antibody [13] was used at a titre of $1: 300$. Both antibodies were combined with a goat-anti-mouse fluorescein- or tetramethyl rhodamine-isothiocyanate (FITC or TRITC) labelled antibody (Nordic Immunological Laboratories, Tilburg, The Netherlands) at a dilution of 1:60 and $1: 15$ respectively or a rabbit-anti-mouse peroxidase conjugated second antibody (Dako, Glostrup, Denmark) at a dilution of 1:100. Double-staining on sections was performed using the fluorescence procedure. H37, an exocrine-specific rat monoclonal antibody [5] (a gift from Dr. O.D. Madsen, Gentofte, Denmark) was used at a dilution of $1: 10$, and combined with N1. As second antibody rabbit-antirat FITC (Dako) at a dilution of 1:80 was used. Both primary and secondary antibodies were applied together. Controls included teplacement of the first antibody with either single- or double-staining using the corresponding animal serum or PBS.

\section{Immunocytochemistry}

These experiments were carried out on cells after Percoll gradient centrifugation. For surface labelling cells were labelled in suspension with a primary antibody in PBS/bovine serum albumin for $30 \mathrm{~min}$ at $4^{\circ} \mathrm{C}$ at a concentration of $1 \times 10^{7}$ per $\mathrm{ml}$. Then they were washed, centrifuged and incubated with a fluorescence-conjugated second antibody for $30 \mathrm{~min}$ at $4^{\circ} \mathrm{C}$. Finally, they were washed once more, cytospins were prepared and fixed in acetone for $15 \mathrm{~min}$ at room temperature. Subsequently, for cytoplasmic labelling, primary and secondary antibodies were applied on the cytospins for 30 min at room temperature. In between, the cytospins were washed with PBS.

The following surface monoclonal antibodies were used: N1, dilution 1:2000, BE2 and 1B2, against pancreatic acinar cells, dilutions 1:10 and 1:1 respectively (a gift from Dr. H.Clausen, Seattle, Wash., USA), ER-Pr7, against pancreatic ductal and acinar cells, 1:5 (a gift from Dr. Th. H. van der Kwast, Rotterdam, The Netherlands). All monoclonal antibodies were of mouse origin. Cytoplasmic antisera used were anti-somatostatin 1:800, anti-vimentin 1:50, anti-glucagon 1:300 (Dako), and anti-islet amyloid polypeptide 1:90 (Peninsula, Belmont, Calif., USA), all were of rabbit origin. A guinea-pig anti-insulin antiserum (Dako) was used at a dilution of 1:1000. The following cytoplasmic monoclonal antibodies were used: mouse anti-synaptophysin 1:10 and anti-tyrosin hydroxylase 1:100 (Boehringer Mannheim), mouse anti-chromogranin A 1:400 (a gift from Dr.J.R.D. Rahier, Brussels, Belgium) and CA812, a BBrat monoclonal autoantibody, 1:100 (a gift from Dr. O.D.Madsen) [5]. Second antibodies were goat-anti-mouse-FITC and TRITC (1:60 and 1:15), goat-anti-rabbit-FITC and TRITC $(1: 80$ and 1:80) (Nordic), goat-anti-guinea-pig-FITC and TRITC (1:60 and 1:15) (Southern Biotechnology, Birmingham, UK) and goat-anti-ratFITC 1:250. Control experiments were performed in single- and
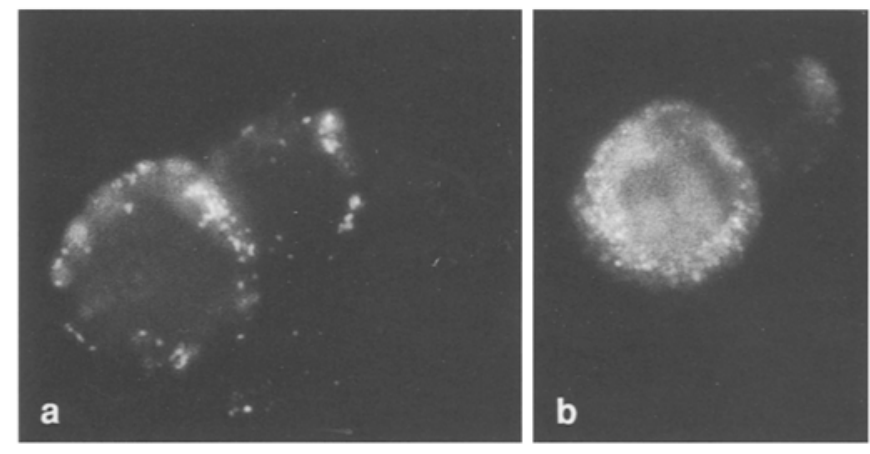

Fig. 2a,b. Pancreatic cell suspension double-stained with N1 (a) and insulin (b). N1 reactivity can be seen on the surface of cells, whereas insulin reactivity is cytoplasmic 
Table 2. Simultaneous positivity of N1 and exocrine, hormonal and other markers in human fetal pancreatic cell preparations

\begin{tabular}{|c|c|c|c|}
\hline Antibody marker & $n$ & $\begin{array}{l}\% \text { positive } \\
\text { cells }\end{array}$ & $\begin{array}{l}\% \text { of } 1 \text {-positive } \\
\text { cells, also positive } \\
\text { for the marker } \\
\text { indicated }\end{array}$ \\
\hline N1 & 25 & $15.6 \pm 5.7$ & 100.0 \\
\hline $\begin{array}{l}\text { BE2 } \\
\text { 1B2 } \\
\text { ER-Pr7 } \\
\text { Vimentin }\end{array}$ & $\begin{array}{l}5 \\
5 \\
5 \\
5\end{array}$ & $\begin{array}{r}21.2 \pm 6.6 \\
11.0 \pm 7.1 \\
8.2 \pm 1.3 \\
45.1 \pm 9.9\end{array}$ & $\begin{array}{l}\text { ND } \\
\text { ND } \\
\text { ND } \\
0.0\end{array}$ \\
\hline $\begin{array}{l}\text { Insulin }^{\mathrm{a}} \\
\text { Glucagon }^{\mathrm{a}} \\
\text { Somatostatin }^{\mathrm{a}} \\
\text { Synaptophysine }^{\mathrm{a}} \\
\text { Tyrosine hydrox. } \\
\text { CA812 } \\
\text { Chromogranin }^{\mathrm{a}} \\
\text { Islet amyloid }^{\text {polvpeptide }}\end{array}$ & $\begin{array}{r}25 \\
14 \\
14 \\
12 \\
6 \\
5 \\
7 \\
9\end{array}$ & $\begin{array}{l}3.0 \pm 1.4 \\
1.2 \pm 0.7 \\
1.9 \pm 0.7 \\
4.1 \pm 1.5 \\
0.3 \pm 0.2 \\
2.0 \pm 0.5 \\
1.4 \pm 0.6 \\
4.0 \pm 1.9\end{array}$ & $\begin{array}{c}16.9 \pm 4.9 \\
6.1 \pm 3.1 \\
14.7 \pm 6.0 \\
24.9 \pm 11.8 \\
1.7 \pm 1.7 \\
12.6 \pm 2.7 \\
9.4 \pm 3.7 \\
22.8 \pm 12.2\end{array}$ \\
\hline
\end{tabular}

a These antibody markers react with a population of cells of which $80-95 \%$ is also reacting with $\mathrm{N} 1$

$n$, number of fetal pancreata (12-18 weeks gestational age)

Results are given as mean $\pm \mathrm{SD} ; \mathrm{ND}$, not done

Table 3. Comparison between human fetal pancreatic cell suspensions at various stages of the procedure for enrichment of single endocrine pancreatic cells: after dispersion and after a 16-h culture period in RPMI 1640 with $10 \%$ human serum

\begin{tabular}{lllll}
\hline Parameter & $n$ & Post-dispersion & Post-culture & $p$-value \\
\hline Yield per pancreas & 15 & $13.3 \times 10^{6}$ cells & $7.9 \times 10^{6}$ cells & - \\
[range] & & {$[5.6-24.7]$} & {$[4.5-14.4]$} & \\
Viable cells (\%) & 15 & $47 \pm 9$ & $56 \pm 13$ & $<0.02$ \\
Single cells (\%) & 18 & $64 \pm 13$ & $89 \pm 10$ & $<0.01$ \\
Insulin cells (\%) & 18 & $2.2 \pm 1.2$ & $3.3 \pm 1.3$ & $<0.02$ \\
\hline
\end{tabular}

$n$, number of pancreata

Data presented (mean \pm SD) in Table 3,4 and 5 come from different series of experiments

double-staining experiments, replacing the primary antiserum with a pre-immune serum or with PBS. No background staining or spectral overlap was observed. Typically 500 to 1000 cells were counted by fluorescence microscopy, excluding disrupted cells from the counting.

\section{Typing and subtyping}

For the determination of the antibody class of N1, goat-anti-mouse antibodies specific for IgM (1:20), IgG1 (1:20), IgG2 (1:10), IgG3 $(1: 10)$ and $\operatorname{IgG} 4(1: 20)$ were used (Nordic). Stainings were performed as described above.

\section{Staining of viable cells}

Fluorescein diacetate (FDA) is a fluorogenic substrate for the determination of cell viability [14]. A stock solution of $1 \mathrm{mg} / \mathrm{ml} \mathrm{FDA}$ in acetone was made and stored at $-20^{\circ} \mathrm{C}$. Cell suspensions were incubated with a 1:10,000 dilution of this stock for $5 \mathrm{~min}$. They were then centrifuged and analysed on a FACScan (Becton Dickinson).

\section{Cell sorting}

Cell sorting experiments were performed on a FACS II cell sorter (Becton Dickinson), equipped with a $5 \mathrm{~W}$ argon laser (Spectra Physics, Mountain View, Calif., USA). Laser power was $250 \mathrm{~mW}$ during all experiments. Cells were labelled for sorting with N1 (titre 1:500) as described. A goat-anti-mouse antibody conjugated to phycoerythrin (PE) at a dilution of 1:20 (Caltag Laboratories, San Francisco, Calif., USA) was used as a second step, since the autofluorescence of the cells interfered with n FITC stain. With excitation at $488 \mathrm{~nm}$, emission was recorded above $580 \mathrm{~nm}$ for PE. For sterile sorting the system was flushed with $70 \%$ ethanol for $15 \mathrm{~min}$, followed by a 15 -min wash with sterile distilled water.

The percentage of N1-positive cells, confirmed by immunocytochemistry, was used to set a window when sorting N1-positive cells. Dead cells, while potentially reactive with $\mathrm{N} 1$, could largely be eliminated on the basis of their different light scattering properties. This difference was confirmed by the FDA viability assay.

\section{Statistical analysis}

The relationship between age and the percentage of cells of a certain type was evaluated according to Spearman's rank correlation. The significance of differences between viability assays before and after Percoll gradient centrifugation was determined by Wilcoxon's signed rank test. All data are given as mean \pm SD .

\section{Results}

\section{Production and screening of monoclonal antibody N1}

One of the hybridoma supernatants stained islets in human adult pancreatic sections. The supernatant was retested on human fetal pancreas and showed positive staining as well. The hybridoma was cloned by limiting dilutions and cloning was repeated to ensure the purity of the cell line. The resulting monoclonal antibody was named $\mathrm{N} 1$ and identified as an IgG1 antibody.

\section{Immunohistochemistry}

N1 immunoreactivity withstands fixation by $4 \%$ buffered formalin, $1 \%$ paraformaldehyde or acetone. Paraffin embedding deletes N1 reactivity. Human and monkey pancreas showed a positive staining reaction, mouse and rat tissue did not. In adult human and monkey pancreas all islet cells were cytoplasmically stained by N1 (Fig.1a).

Table 4. Comparison between human fetal pancreatic cell suspensions at various stages of the procedure for enrichment of single endocrine pancreatic cells: after a 16-h culture period in RPMI 1640 with $10 \%$ human serum and after Percoll gradient centrifugation

\begin{tabular}{lllll}
\hline Parameter & $n$ & Post-culture & Post-Percoll & $p$-value \\
\hline Yield per pancreas & 18 & $13.4 \times 10^{6}$ cells & $7.2 \times 10^{6}$ cells & - \\
[range] & & {$[6.0-23.6]$} & {$[2.7-12.4]$} & \\
Viable cells $(\%)$ & 19 & $54 \pm 8$ & $81 \pm 4$ & $<0.01$ \\
Insulin cells $(\%)$ & 13 & $2.1 \pm 0.6$ & $2.8 \pm 1.1$ & NS \\
\hline
\end{tabular}

$n$, number of pancreata

Data presented (mean \pm SD) in Table 3,4 and 5 come from different series of experiments 

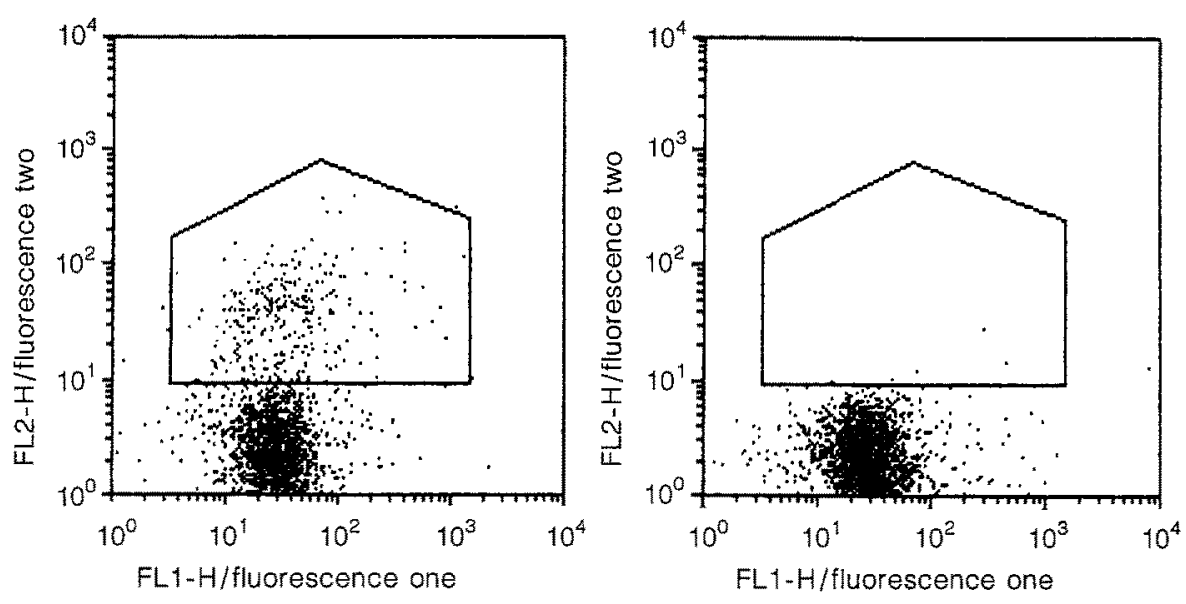

Fig. 3. Dot plots showing the fluorescence distribution of a pancreatic cell suspension labelled with N1 (left panel) and a pancreatic cell suspension labelled with an irrelevant antibody (right panel). This picture was produced on a FACStar-plus cell sorter and attached software, courtesy of Becton Dickinson, Erembodegem, Belgium

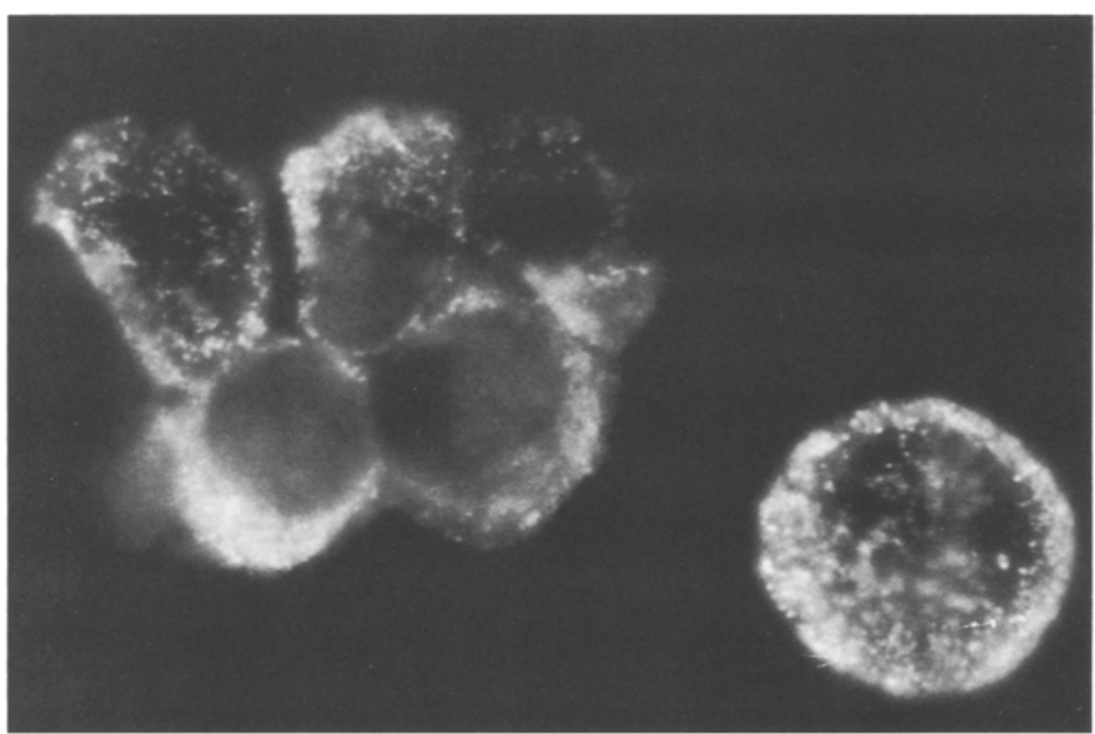

Fig. 4. Fluorescent picture of a pancreatic cell preparation following cell sorting. Numerous insulin-positive cells can be seen
This was confirmed by staining serial sections with $\mathrm{N} 1$ and with insulin. Double-staining with N1 and H37, a marker for exocrine pancreatic cells, showed no overlap between these markers in the human adult pancreas. In the human fetal pancreas groups of cells and single cells, dispersed throughout the parenchyma were stained by N1 (Fig. 1 b). Double-staining showed that some of these cells contained insulin. The reactivity of N1 in other human fetal organs is summarized in Table 1.

\section{Immunocytochemistry}

Human fetal pancreatic cell suspensions showed N1 reactivity on the surface of cells (Fig. 2a). No overlap was seen between $\mathrm{N} 1$ and vimentin, a marker of mesenchymal cells. There were no insulin-positive cells staining with exocrine cell monoclonal antibodies, specific for acinar as well as ductal cells. Double-staining for N1 and hormonal markers (insulin, glucagon, somatostatin) or for $\mathrm{N} 1$ and either synaptophysin, tyrosin hydroxylase, CA812, chromogranin A or islet amyloid polypeptide further characterized the population of N1-positive cells (Table 2, Fig. $2 \mathrm{a}, \mathrm{b})$. In some cases two mouse monoclonal anti- bodies were used subsequently. Incubation with $\mathrm{N} 1$ and its conjugate was done in suspension, as described, followed by the preparation of cytospins and fixation. Because of this procedure, and the spatial difference of the staining pattern (surface labelling for N1 vs cytoplasmic labelling for the other antibody) cells could be recognized and scored without interference of cross-reactivity. Doublestainings performed with each of the five markers above combined with each of the three hormone antibodies showed that $40 \%$ of synaptophysin-positive cells, $50 \%$ of chromogranin A-positive cells, $50 \%$ of CA812-positive cells, $60 \%$ of islet amyloid polypeptide-positive cells and $100 \%$ of tyrosin hydroxylase-positive cells did not contain one of the three hormones (unpublished results).

Hence, the five subpopulations added to characterize N1-positive cells. Together they contributed 35-40\% of the population of N1-positive cells. Overlap between the populations stained by each of the five markers remains possible, reducing this percentage. Between 12 and 18 weeks gestational age the percentage of N1-positive cells increased from 10 to $19 \%\left(n=29, r_{\mathrm{s}}=0.57\right.$, $p<0.01$ ). At the same time there was a similar increase of insulin-positive cells $\left(n=21, r_{\mathrm{s}}=0.45, p<0.05\right)$, but not of Alpha and Delta cells. The proportion of hormone-con- 
Table 5. Comparison between human fetal pancreatic cell suspensions at various stages of the procedure for enrichment of single endocrine pancreatic cells: after Percoll gradient centrifugation and after fluorescence activated cell sorting of N1-labelled cells

\begin{tabular}{lrlll}
\hline Parameter & $n$ & Post-Percoll & Post-sorting & $p$-value \\
\hline Yield per pancreas & 10 & $7.4 \times 10^{6}$ cells & $0.5 \times 10^{6}$ cells - \\
[range] & & {$[3.2-13.0]$} & {$[0.2-0.7]$} & \\
Viable cells (\%) & 5 & $80 \pm 6$ & $63 \pm 10$ & $<0.05$ \\
Insulin cells (\%) & 10 & $3.0 \pm 1.4$ & $16.2 \pm 4.8$ & $<0.01$ \\
Glucagon cells (\%) & 8 & $1.2 \pm 0.7$ & $5.7 \pm 2.0$ & $<0.01$ \\
Somatostatin cells (\%) & 8 & $1.9 \pm 0.7$ & $6.8 \pm 2.1$ & $<0.01$ \\
N1 cells (\%) & 5 & $17 \pm 4$ & $83 \pm 6$ & $<0.05$ \\
Vimentin cells (\%) & 6 & $47 \pm 10$ & $26 \pm 7$ & $<0.02$ \\
\hline
\end{tabular}

$n$, number of pancreata

Data presented (mean \pm SD) in Table 3,4 and 5 come from different series of experiments

taining cells in the N1 population did not significantly change.

\section{Dispersion}

Because pancreatic weight increased from $50 \mathrm{mg}$ at 12 weeks gestational age to $250 \mathrm{mg}$ at 18 weeks, there was a considerable variation in the cell yield between pancreata (Table 3 ). The yield per amount of tissue was relatively constant throughout this age range: $1.29 \pm 0.17 \times 10^{5}$ cells per mg pancreatic tissue $(n=10$, mean \pm SD). There was virtually no tissue remaining after the second collagenase digestion step and the passage through the $100 \mu \mathrm{m}$ nylon mesh. There was no correlation between cell yield per weight and the age of the processed specimen $\left(r_{s}=0.18\right)$.

\section{Overnight culture}

Recovery of the cell number following culture in RPMI 1640 plus $10 \%$ human serum and $1.5 \mathrm{U} / \mathrm{ml}$ dispase was $66 \pm 28 \% \quad(n=15)$. At the same time the percentage of single cells and the percentage of insulin-positive cells increased (Table 3). Cells were not attached to the dishes, nor was there any clumping. Omission of dispase resulted in extensive clumping and cell attachment at the present cell concentration.

\section{Gradient centrifugation}

Percoll gradient centrifugation resulted in two interphases and a pellet. The viability of the $1.004-1.030 \mathrm{~g} / \mathrm{ml}$ interphase was $48 \pm 22 \%$, that of the $1.030-1.063 \mathrm{~g} / \mathrm{ml}$ interphase was $83 \pm 5 \%$ and that of the pellet was $20 \pm 8 \%$, as compared with $53 \pm 8 \%$ in the initial cell suspension $(n=7)$. There was a large number of erythrocytes present in the pellet. The difference in viability between the $1.030-1.063 \mathrm{~g} / \mathrm{ml}$ interphase and the initial cell suspension was significant $(p<0.01)$ (Table 4$)$. The recovery of cells in the viable interphase was $55 \pm 12 \%(n=18)$.

\section{Cell sorting}

Fluorescence activated cell sorting of N1-positive cells (Fig.3) resulted in an increase of the percentage of insulincontaining cells (Fig. 4). Also glucagon- and somatostatinpositive cells were enriched significantly (Table 5). After sorting, $6.2 \pm 2.7 \%(n=10)$ of the cells which were obtained after Percoll gradient centrifugation, were recovered in the enriched suspension. During the sorting procedure the viability decreased (Table 5). The final recovery of Beta cells after all the procedures (from dispersion to sorting) was $11.3 \pm 3.6 \%(n=10)$ as compared to a recovery of $2.2 \pm 1.1 \%$ for all cells.

\section{Discussion}

We describe the production of a monoclonal antibody, N1, reactive to the surface and cytoplasm of islet cells in the human fetal and adult pancreas. Apparently, its epitope is present early in development and persists throughout adulthood. N1 does not react to exocrine or mesenchymal cells, confirming its endocrine specificity within the pancreas. Outside the pancreas, N1 reactivity was found in several other tissues and was not restricted to endocrine cells.

Almost $40 \%$ of N1-positive cells in the fetal pancreas contained either insulin, glucagon or somatostatin. Since cells were cultured for at least $16 \mathrm{~h}$ before staining, it is unlikely that this binding pattern is influenced by the dispersion process. Five other markers (islet amyloid polypeptide, synaptophysin, chromogranin A, tyrosine hydroxylase and CA812) also constitute $35-40 \%$ of N1positive cells. By combining these markers with antibodies to insulin, glucagon and somatostatin, overlapping populations were observed. Only hormone-negative subpopulations of cells positive with one of the five markers were used for further characterization of N1-positive cells. Synaptophysin is present on the membrane of secretory granules of islet cells [16] or in synaptic-like microvesicles [17]. Chromogranin A is converted to betagranin and cosecreted with insulin [18]. Islet amyloid polypeptide is colocalized with insulin in Beta-cell secretory granules [19].

Recently, it has been suggested that islet amyloid polypeptide is present in more immature cells $[20,21]$. The expression of synaptophysin, chromogranin A and islet amyloid polypeptide in cells not containing insulin, glucagon or somatostatin is intriguing. Apparently, cells with (neuro)endocrine characteristics are present which do not contain hormones. Alternatively, these cells may have lost their hormone or hormone production in vitro or through the various experimental procedures.

The increase in the percentage of N1-positive cells from 10 to $19 \%$, between 12 and 18 weeks gestational age might represent a period with rapid endocrine cell proliferation and/or differentiation relative to the rest of the pancreas. A concomitant increase in the percentage of insulin-positive cells resulted in an unaltered ratio of insulin-vs N1-positive cells.

Many procedures exist for the recovery of islets from the adult pancreas [22-27]. The scattered distribution of 
endocrine cells in the human fetal pancreas excludes standard islet isolation procedures [9]. Instead we dispersed the whole pancreas into single cells allowing cell sorting. Our method resulted in considerable cell death, probably due to the use of collagenase. Therefore, Percoll gradient centrifugation was performed to increase the percentage of viable cells before antibody labelling and cell sorting. The clumping tendency of the preparations results in a suboptimal percentage of viable cells.

For the enrichment of Beta cells, van de Winkel et al. [28] were able to sort rat Beta cells from other endocrine pancreatic cells on the basis of flavin adenine dinucleotide (FAD) content [29] resulting in autofluorescence. We could not increase the percentage of fetal Beta cells using this method (unpublished results), or by using forward light scatter as a sorting parameter as previously described for rat islet cells $[30,31]$. The observed differences may be the result of the human or fetal character of these pancreatic cells.

Therefore we labelled the surface of the cells with $\mathrm{N} 1$, while in suspension. Enrichment is limited by the proportion of Beta cells in the N1-positive cell population $(16.9 \pm 4.9 \%)$. Some contamination with mesenchymal cells is present. This may be caused by non-specific binding of label to these cells or the formation of doublets with N1-positive cells. The decrease in viability after sorting may result from dead cells with false positive N1 reactivity, although care was taken to eliminate these on the basis of light scattering properties. Moreover, the stress of the sorting procedure might result in a decreased viability.

Preliminary experiments have shown that the sorted cell suspension can be cultured for up to 1 week, without a decrease in viability or the percentage of endocrine cells (unpublished results). The enriched suspensions may be used to further address questions about the exact development of endocrine pancreatic cells and the order of expression of relevant markers.

In conclusion, an antibody was produced which reacts to the surface and cytoplasm of islet cells in the human fetal pancreas. With this antibody we have been able to enrich Beta cells and other endocrine cells from a total pancreatic cell preparation by fluorescence activated cell sorting.

Acknowledgements. The authors would like to acknowledge Mr. M. Kuit for photographic assistance. They thank Dr. O. Madsen and Mrs. E.E.Pedersen for their excellent immunohistochemical stainings. H.J. A. is supported by a stipend from the "Ter Meulen Foundation". R.R.de K. and G.K. are supported by a grant from the Dutch Diabetes Research Fund.

\section{References}

1. Ziegler B, Witt S, Waterstradt B, Schlosser M, Ziegler M(1989) Heterogeneity of monoclonal antibodies against pancreatic Beta cells. Exp Clin Endocrinol 93: 173-180

2. Witt S, Ziegler B, Waterstradt B, Besch W, Hehmke B, Ziegler M (1987) Generation and partial characterization of monoclonal antibodies reactive with islet cell antigens. Exp Clin Endocrinol $89: 276-282$
3. Vissing H, Papadopoulos G, Lernmark $\AA$ (1986) Monoclonal antibodies against pancreatic islet-cell-surface antigens selected by flow cytofluorometry. Scand J Immunol 23: 425-433

4. Brogren C-H, Hirsch F, Wood P, Druet P, Poussier P (1986) Production and characterization of a monoclonal islet cell surface autoantibody from the BB rat. Diabetologia 29: 330-333

5. Contreas G, Jorgensen J, Madsen OD (1990) Novel islet, duct, and acinar cell markers defined by monoclonal autoantibodies from prediabetic BB rats. Pancreas 5: 540-547

6. Gerbitz KD, Boenke B, Paprotta A, Chemnitz U (1988) Human nesidioblastosis tissue as an immunogen for generation of islet cell specific monoclonal antibodies. I Clin Chem Clin Biochem 26: $659-666$

7. Warnock GL, Kneteman NM, Evans MG, Dabbs KD, Rajotte RV (1990) Comparison of automated and manual methods for islet isolation. Can J Surg 33: 368-371

8. Van de Winkel M, Maes E, Pipeleers DG (1982) Islet cell analysis and purification by light scatter and autofluorescence. Biochem Biophys Res Comm 107: 525-532

9. Like AA, OrciL (1972) Embryogenesis of the human pancreatic islets: a light and electron microscopic study. Diabetes 21 [Suppl 2]: $511-534$

10. Milstein C, Galfre G, Secher DS, Springer T (1979) Monoclonal antibodies and cell surface antigens. Cell Biol Int Rep 3:1-16

11. Nakane PK, Pierce GB (1967) Enzyme-labelled antibodies for the light and electron microscopic localization of tissue antigens. J Cell Biol 33:307-318

12. Wicker R, Avrameas S (1969) Localization of virus antigens by enzyme-labelled antibodies. J Gen Virol 4: 465-471

13. Keilacker H, Dietz H, Witt S, Woltanski KP, Berling R, Ziegler M (1986) Kinetic properties of monoclonal insulin antibodies. Biomed Biochim Acta 45: 1093-1102

14. Rotman B, Papermaster BW (1966) Membrane properties of living mammalian cells as studies by enzymatic hydrolysis of fluorogenic esters. Proc Natl Acad Sci USA 55: 134-141

15. Roth J, Bendayan M, Carlemalm E, Villiger W, Garavitto M (1981) Enhancement of structural preservation and immunocytochemical staining in low temperature embedded pancreatic tissue. J Histochem Cytochem 29: 663-671

16. Kalina M, Lukinius A, Grimelius L (1991) Ultrastructural localization of synaptophysin to the secretory granules of normal glucagon and insulin cells in human islets of Langerhans. Ultrastruct Pathol 15:215-219

17. Navone F, Jahn R, Di Giola G, Stukenbrok H, Greengard P, De Camilli $P$ (1986) Protein p38: an integral membrane protein specific for small vesicles of neurons and neuroendocrine cells. J Cell Biol 103: 2511-2527

18. Hutton JC (1989) The insulin secretory granule. Diabetologia 32: $271-281$

19. Lukinius A, Wilander E, Westermark GT, Engström U, Westermark P (1989) Co-localization of islet amyloid polypeptide and insulin in the $\mathrm{B}$-cell secretory granules of the human pancreatic islets. Diabetologia 32: 240-244

20. Madsen OD, Blume N, Petersen JE, Kofod H, Dyrberg T (1990) Specific antisera to IAPP, proinsulin C-peptide 1, and 2: probes to study murine islet Beta-cell differentiation. Diabetologia 33 [Suppl]: A108 (Abstract)

21. Madsen OD, Nielsen JH, Michelsen B et al. (1991) Islet amyloid polypeptide and insulin expression are controlled differently in primary and transformed islet cells. Mol Endocrinol 5: 143-148

22. Hegre OD, Marshall S, Schulte BA et al. (1983) Nonenzymic in vitro isolation of perinatal islets of Langerhans. In Vitro 19: 611620

23. Ono J, Takaki R, Fukuma M (1977) Preparation of single cells from pancreatic islets of adult rat by the use of dispase. Endocrinol Jpn 24:265-270

24. Pipeleers DG, In't Veld PA, Van de Winkel M, Maes E, Schuit FC, Gepts W (1985) A new in vitro model for the study of pancreatic $A$ and $B$ cells. Endocrinology 117: 806-816

25. Kover K, Moore WV (1989) Development of a method for isolation of islets from human fetal pancreas. Diabetes 38: 917-924 
26. Hellerström C, Lewis NJ, Borg H, Johnson R, Freinkel N (1979) Method for large-scale isolation of pancreatic islets by tissue culture of fetal rat pancreas. Diabetes 28: 769-776

27. Korsgren O, Sandler S, Schnell Landstrom A, Jansson L, Andersson A (1988) Large-scale production of fetal porcine pancreatic islet-like cell clusters. An experimental tool for studies of islet cell differentiation and xenotransplantation. Transplantation 45: 509-514

28. Van de Winkel M, Maes E, Pipeleers DG (1982) Islet cell analysis and purification by light scatter and autofluorescence. Biochem Biophys Res Comm 107: 525-532

29. MacDonald MJ (1981) Flavin content of intracellular compartments of pancreatic islets compared with acinar tissue and liver. Endocrinology 108: 1899-1902

30. Rabinovitch A, Russell T, Shienvold F et al. (1982) Preparation of rat islet B-cell-enriched fractions by light-scatter flow cytometry. Diabetes 31: 939-943
31. Nielsen DA, Lernmark $\AA$, Berelowitz M, Bloom GD, Steiner DF (1982) Sorting of pancreatic islet cell subpopulations by light scattering using a fluorescence activated cell sorter. Diabetes 31: 299-306

Received: 16 May 1991

and in revised form: 18 December 1991

Dr. R. R. de Krijger

Erasmus University Rotterdam

Department of Clinical Genetics, Room 2434

P.O. Box 1738

NL-3000 DR Rotterdam

The Netherlands 